\title{
A simple and feasible process for using multi-stage high-precision DTMs, field surveys and rainfall data to study debris flow occurrence factors of Shenmu area, Taiwan
}

\author{
W.-C. Lo ${ }^{1}$, B.-S. Lin ${ }^{2}$, H.-C. Ho ${ }^{2}$, J. Keck ${ }^{2}$, H.-Y. Yin ${ }^{3}$, and H.-Y. Shan ${ }^{1}$ \\ ${ }^{1}$ Department of Civil Engineering, National Chiao Tung University, Hsinchu, Taiwan \\ ${ }^{2}$ Disaster Prevention Technology Research Center, Sinotech Engineering Consultants, Taiwan \\ ${ }^{3}$ Soil and Water Conservation Bureau, Council of Agriculture, Taiwan \\ Correspondence to: B.-S. Lin (bosch.lin@ sinotech.org.tw)
}

Received: 30 January 2012 - Revised: 14 October 2012 - Accepted: 17 October 2012 - Published: 20 November 2012

\begin{abstract}
The occurrence of typhoon Herb in 1996 caused massive landslides in the Shenmu area of Taiwan. Many people died and stream and river beds were covered by meters of debris. Debris flows almost always take place in the Shenmu area during the flood season, especially in the catchment areas around Tsushui river and Aiyuzih river. Anthropogenic and natural factors that cause debris flow occurrences are complex and numerous. The precise conditions of initiation are difficult to be identified, but three factors are generally considered to be the most important ones, i.e. rainfall characteristics, geologic conditions and topography. This study proposes a simple and feasible process that combines remote sensing technology and multi-stage high-precision DTMs from aerial orthoimages and airborne LiDAR with field surveys to establish a connection between three major occurrence factors that trigger debris flows in the Shenmu area.
\end{abstract}

\section{Introduction}

The Shenmu area, which is located in the central part of Taiwan, is generally affected by debris flows during the typhoon and flood seasons and has the highest debris flow frequency throughout Taiwan. Due to the high frequency of debris flows, and because approximately 1000 people live in this highly mountainous area, great damage potential exists. Resultantly, many researchers and considerable resources have been involved to study the lithology, hydrology as well as geomorphology of the Chen-yo-lan river basin, which includes the Shenmu area. It is well known that many authors have reached substantial conclusions regarding the occurrence of debris flows, the flow characteristics of debris flows, the variations in debris flow occurrence, and debris flow disasters, even if more research is needed to improve the results obtained hitherto (Harris, 1977; Takahashi, 1978; Sidle et al., 1985; VanDine, 1985; Ashida et al., 1983; Anderson and Sitar, 1991; Arattano and Franzi, 2004; Imaizumi et al., 2008; Guzzetti et al., 2008; Passmore et al., 2008; Lin et al., 2011). According to the obtained results, a large number of both anthropogenic and natural factors are known to affect the occurrence of debris flows. Only field observation and repeated surveys can allow for good evidence about debris flow occurrence (Johnson, 1970; Pierson, 1986; Pierson and Costa, 1987; Arattano and Franzi, 2004; Jakob and Hungr, 2005; Arattano et al., 2010). Using remote sensing, field investigation, and other analysis techniques, this study evaluates debris flow occurrence and magnitude with respect to three general debris flow elements: rainfall characteristics, geologic conditions and topography.

\section{Overview of environment}

\subsection{Study area}

As illustrated in Fig. 1, the Shenmu area is located in the southwestern corner of Nantou County, in a fold-thrust belt that makes up the western foothills of Taiwan. Topography is characterized by tall mountains and steep slopes, with elevations ranging from $500 \mathrm{~m}$ a.s.1. to $2500 \mathrm{~m}$ a.s.l. The Shenmu area steeper than $28.8^{\circ}$ represents $45 \%$ of the total regional 


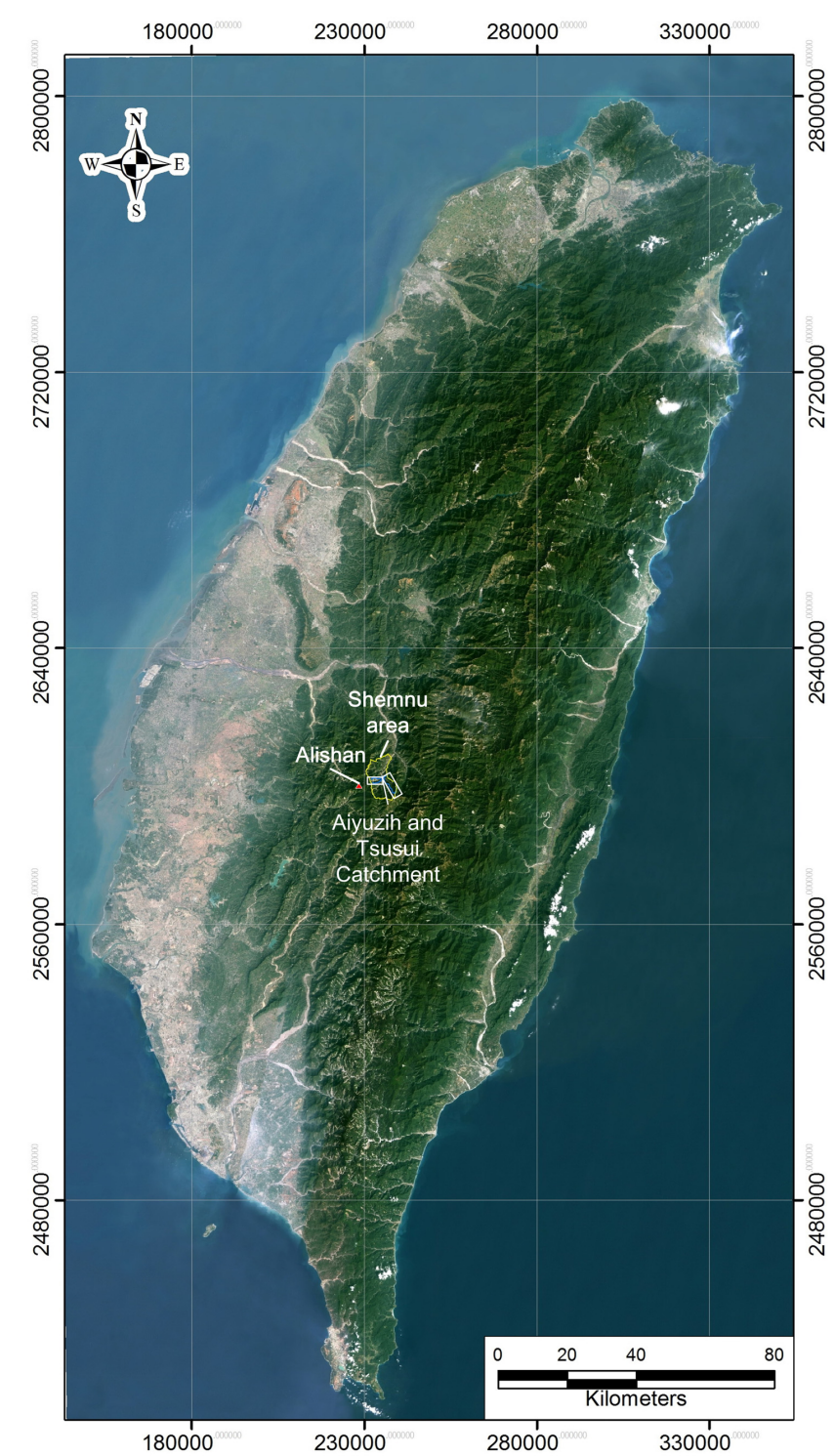

Fig. 1. Graphical location of Tsushui river and Aiyuzih river catchment in Taiwan.

extension $\left(72.16 \mathrm{~km}^{2}\right)$ and $47.75 \%$ of the slopes are northfacing. The Shenmu area is crossed by three primary geologic structures: the northeast-southwest Heshe anticline and Tungfu syncline and the Chen-you-lan fault. Densely forested mountain slopes are built up by the Nanchuang and Heshe formation (see Fig. 2). These formations consist mainly of hard, dark grey argillite and grey slate with thinly bedded muddy sandstone, which are prone to more severe weathering and become weak layers in the rock strata. These geologic conditions make the slope unstable under heavy rainfall and strong earthquake shaking. Hence, during the typhoon and flood season, the combination of huge rainfalls and local weak geological conditions easily permit the occurrence of debris flows. As a consequence, the debris flows

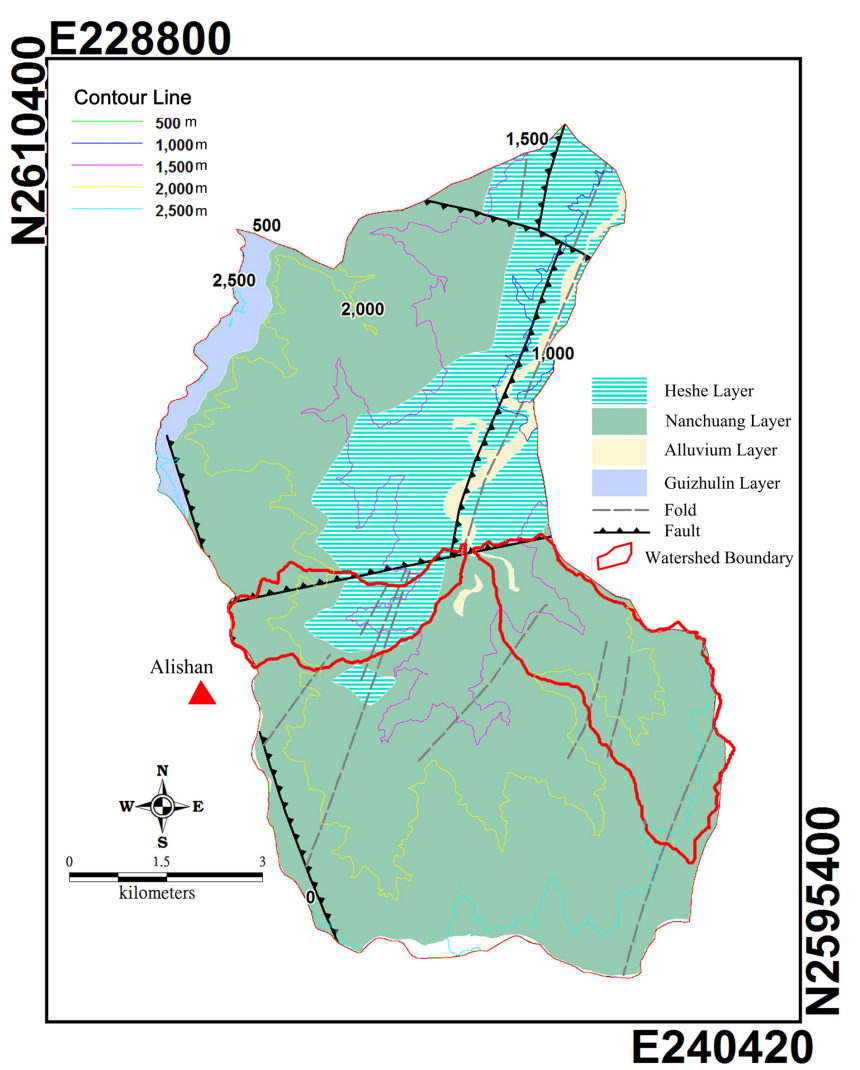

Fig. 2. Geological map of Shenmu area.

cause structural damages to the check dams located there (see Fig. 3) and endanger inhabited areas, properties and residents at risk (Franzi, 2012).

\subsection{Hydrology}

The Shenmu area is located in the Heshe river watershed, an upstream watershed of the Chen-yo-lan river. The Aiyuzih, Hossa and Tsushui rivers constitute the Heshe river watershed. Temperature ranges from $5.9^{\circ}$ to $14.4^{\circ}$, averaging $10.9^{\circ}$ annually. Average annual accumulated rainfall for three weather monitoring stations located at Alishan, Shenmu Village, and Hsinkaoko ranges from 1950 to $4980 \mathrm{~mm}$. According to hydrologic analysis based on 1961 to 2000 typhoon rainfall data, the results indicate the rainfall center of Taiwan is close to Alishan Mountain (see Fig. 4). Recent extreme rainfalls have caused annual accumulated rainfall of Taiwan to increase, especially for Alishan, where, since 2005, annual rainfalls have exceeded $5000 \mathrm{~mm}$ (see Fig. 5). This rate is double the annual average precipitation $(2500 \mathrm{~mm})$ for Taiwan and over four times the world annual average precipitation. 


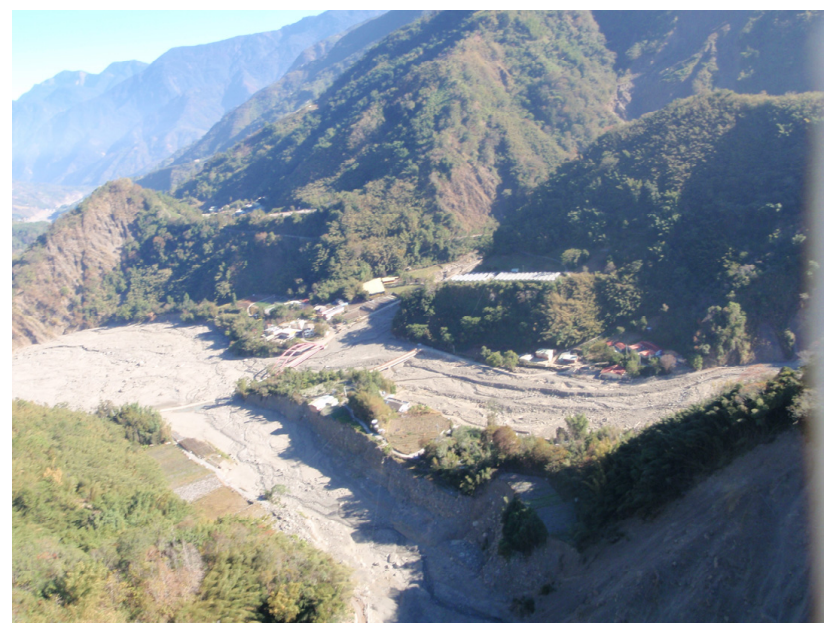

(a)

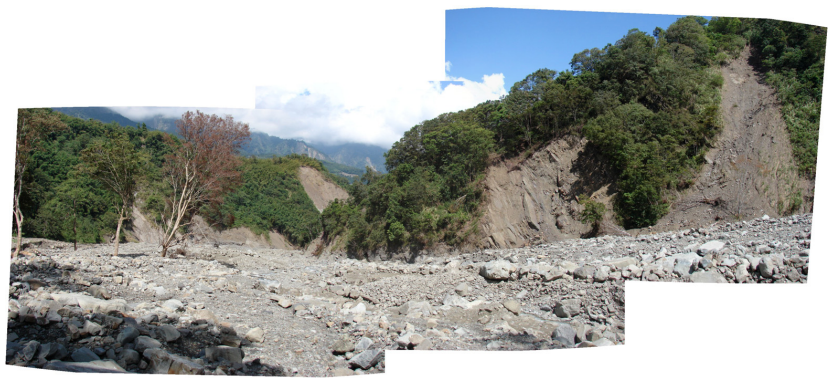

(b)

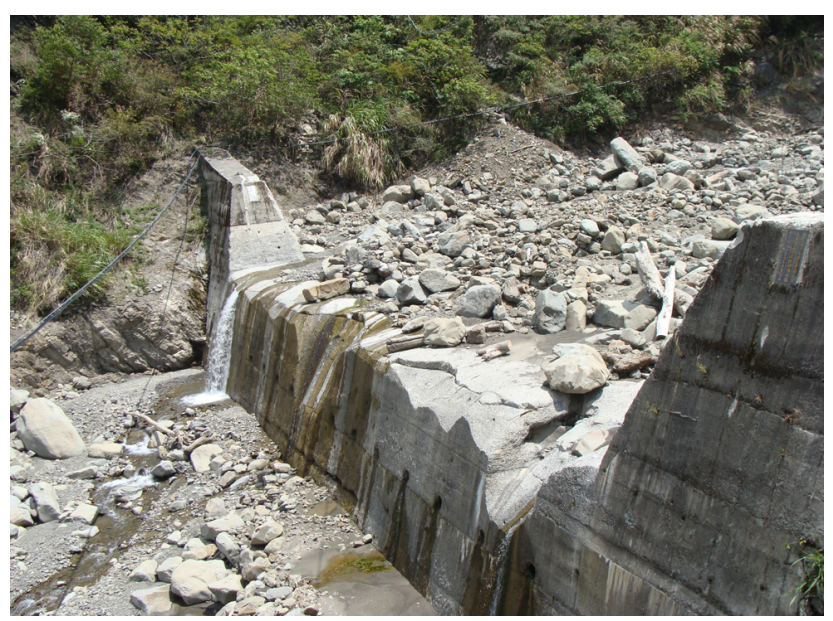

(c)

Fig. 3. Photos of damage-induced debris flow in Shenmu area after typhoon Morakot. (a) Sediment disaster causes road closure at the confluence of Tsushui and Aiyuzih rivers. (b) Large amount of sediment material deposited in river bed. (c) Failure of check dam in Tsushui river.

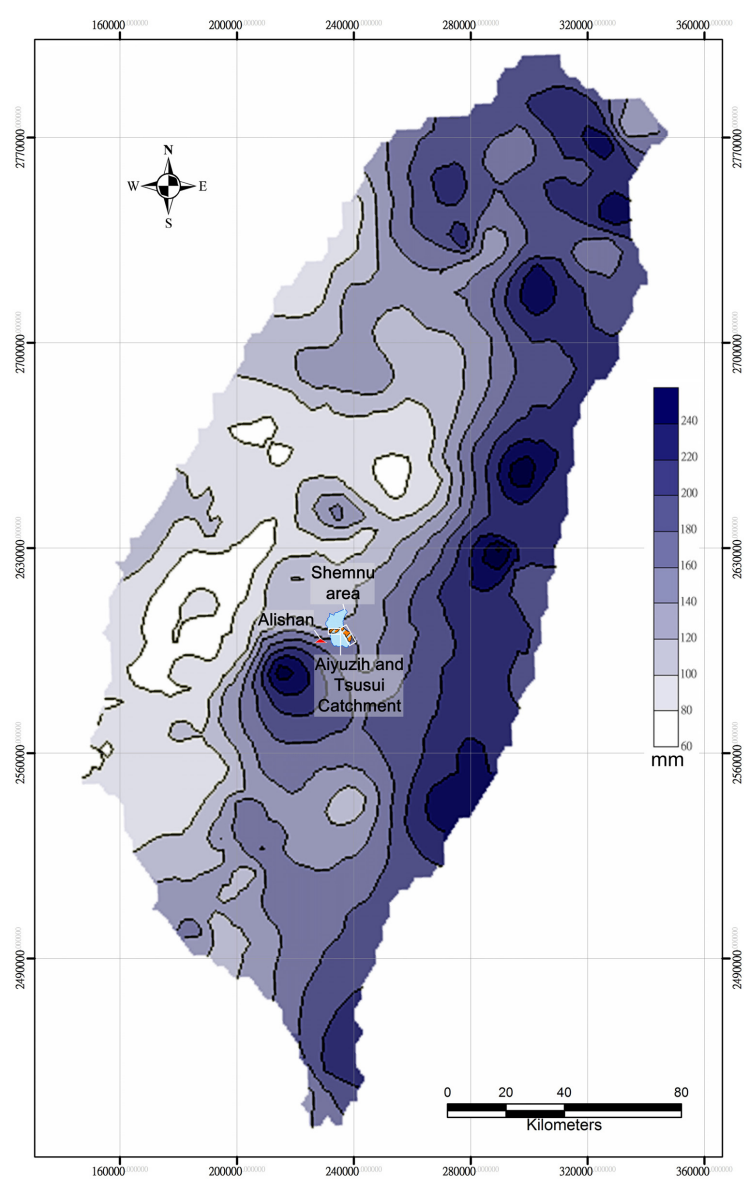

Fig. 4. Distribution of average annual rainfall 1961-2000 (Water Resources Agency, http://wrb.gov.tw).

\subsection{Major typhoon events and subsequent suspended sediment}

Under the effect of global climate change, the probability of extreme weather occurrence has increased. In the mountain area, it can be observed that the magnitude of disasters caused by water-sediment flows, induced by high intensity and long duration rainfall events, has increased. The mode of sediment transport can be classified in different ways (Einstein, 1964), according to the mechanics of sediment transport process, from suspended load to debris flow (Franzi, 2002). In general, measurements of sediment concentrations in a flow depend on accurate field instrumentation to identify the process of water-sediment flow (Arattano and Franzi, 2004). In particular, suspended loads of sediment can be measured by depth-integrating suspended-sediment sampling from water-sediment current (Nilsson, 1969). However, measurement of sediment concentration in debris flows is very difficult and often impracticable. The variations in time of the sediment, carried by water discharge, can represent the upstream hydrologic conditions in modeling the process (Vanoni, 2006). However, as far as hazard assessment 


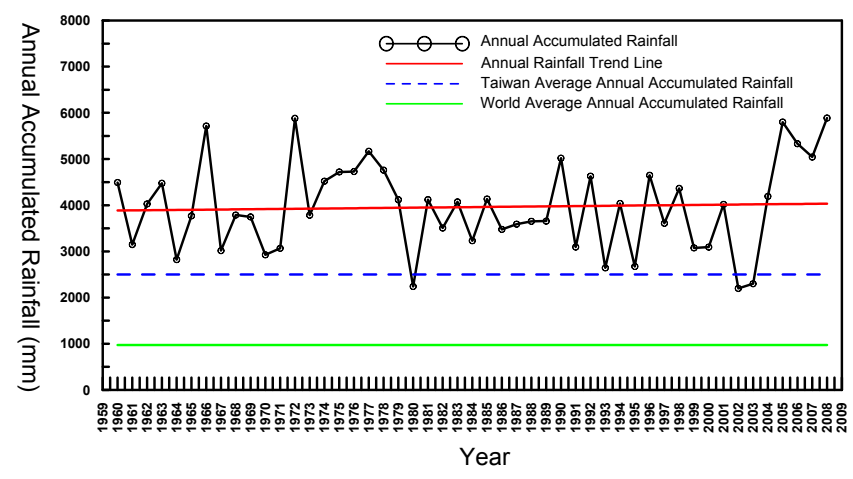

Fig. 5. Time series of annual rainfalls at Alishan.

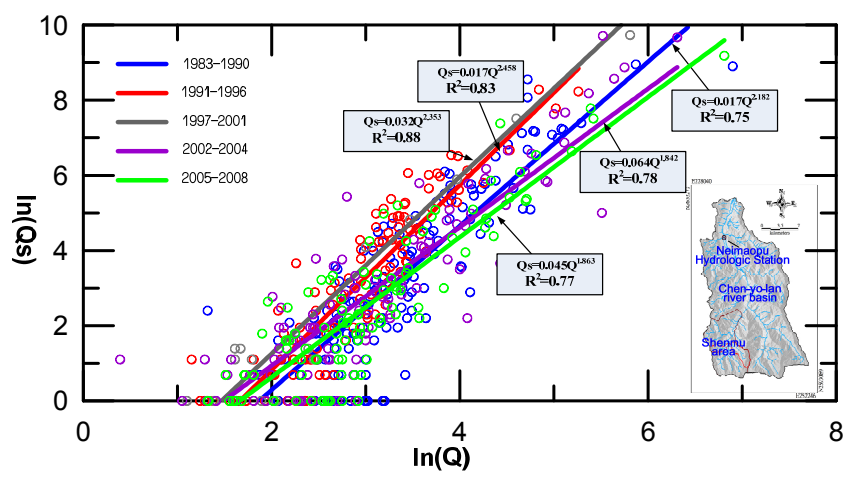

Fig. 6. The relationship of peak daily water discharges $(Q)$ and suspended sediment $\left(Q_{\mathrm{S}}\right)$ at the Neimaopu hydrologic station in Shenmu area.

is concerned, forecasting the kind of water-sediment flows that originates during extreme rainfall is a very difficult task (Franzi, 2012).

For understanding sediment transport process triggered by major typhoon events, this study collected suspended sediment records from 1983 to 2008 obtained from the Taiwan Water Resources Agency Neimaopu Hydrologic Station downstream of the Shenmu area. A regression analysis has been carried out by referring to five time periods, for which the major typhoon events may be referred to in Table 1. Actually, in each period, from an empirical point of view, the sediment carried by the current seems to follow a different trend. For each period a relationship between the daily peak water discharge and the transported sediment has been obtained (see Fig. 6). Results of suspended sediment clearly varied for each of the five typhoon periods. It can be seen that from 2002 to 2004, the catchment sediment yields gradually seem to be close to the pre-1990-level. From 2004 to 2008, the catchment sediment yields dropped to pre-1990 levels. This decrease may be explained by measurement uncertainties, due to the fact that sediment volumes, transported by the current (during the 1999 Chi-Chi Earthquake which occurred in the period 1997-2001) bypassed the station.

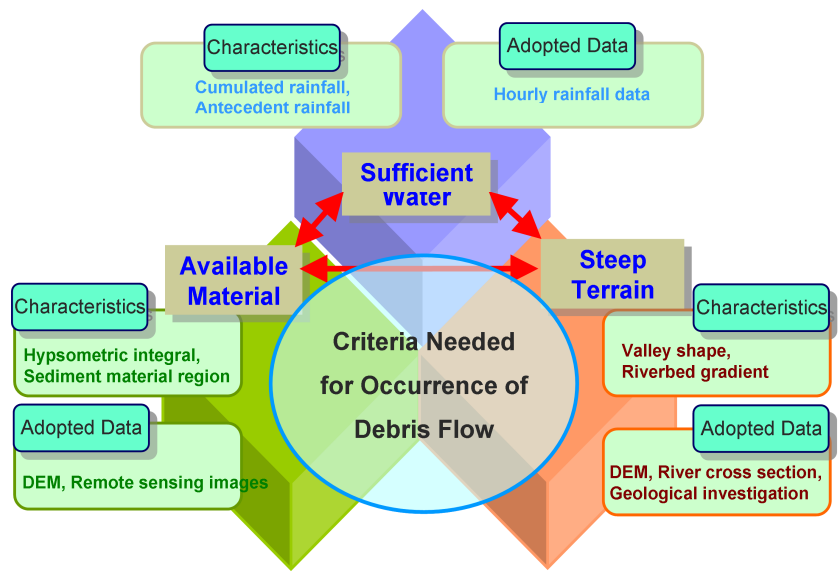

Fig. 7. Correlation among the three major debris flow occurrence factors.

\section{Investigation methods}

Conditions necessary for debris flow occurrence in the Tsushui and Aiyuzih rivers were evaluated using basic hydrologic, geologic and topographic characteristics (see Fig. 7). Effective rainfall and rainfall intensity records were correlated with real debris flow cases. High-precision digital terrain and airborne LiDAR DTM datasets were used to identify debris flow material sources and quantify the hypsometric integrals of the two catchment areas. Topographic changes of the river valley associated with debris flow scour and deposition were identified by means of multi-stage highprecision DTMs, in situ river cross section measurements obtained using a total station, and a geological survey.

\subsection{Rainfall event analysis}

In order to examine the relationship between rainfall distribution and debris flow occurrence, 27 rainfall events, recorded between 2002 and 2009, were collected for the Tsushui and Aiyuzih rivers. Pictures of damages caused by the debris flows show the evidence of debris flow occurrence (Soil and Water Conservation Bureau, http://246.swcb.gov.tw/history/ history-greatcase.asp). For this study, the definition of rainfall event by the Taiwan Central Weather Bureau has been used, according to which rainfall event is "any rainfall in which hourly rainfall exceeded $4 \mathrm{~mm} \mathrm{~h}^{-1}$ " as shown in Fig. 8 (Jan et al., 2003). The first hour in which hourly rainfall exceeded $4 \mathrm{~mm} \mathrm{~h}^{-1}$ is designated as the beginning time of the event. The final consecutive six hours of this event having an intensity less than $4 \mathrm{~mm} \mathrm{~h}^{-1}$ is designated as the ending time of the event. Regarding the correlation of rainfall characteristic and debris flow occurrence, the rainfall intensity equal to $4 \mathrm{~mm} \mathrm{~h}^{-1}$ may be considered the lower threshold for debris flows occurrence, while the time of occurrence is close to maximum rainfall intensity (Jan et al., 2003; Shieh et al., 2009). In addition to rainfall intensity, debris 
Table 1. Rainfall parameters from heavy rains with debris flows.

\begin{tabular}{|c|c|c|c|c|c|}
\hline \multirow[t]{2}{*}{ Year } & \multirow[t]{2}{*}{ Event } & \multicolumn{2}{|c|}{$\begin{array}{l}\text { Aiyuzih river } \\
\text { catchment area }\end{array}$} & \multicolumn{2}{|c|}{$\begin{array}{c}\text { Tsushui river } \\
\text { catchment area }\end{array}$} \\
\hline & & $\begin{array}{r}\text { effective accumulated } \\
\text { rainfall }(\mathrm{mm})\end{array}$ & $\begin{array}{r}\text { rainfall intensity } \\
\left(\mathrm{mm} \mathrm{h}^{-1}\right)\end{array}$ & $\begin{array}{r}\text { effective accumulated } \\
\text { rainfall }(\mathrm{mm})\end{array}$ & $\begin{array}{l}\text { rainfall intensity } \\
\qquad\left(\mathrm{mm} \mathrm{h}^{-1}\right)\end{array}$ \\
\hline 2003 & 67 Heavy Rain & 228.1 & 20.5 & - & - \\
\hline 2004 & 521 Heavy Rain & 143.1 & 40.5 & - & - \\
\hline 2004 & Mindulle & 333.3 & 24.5 & - & - \\
\hline 2005 & Talim & - & - & 204.6 & 25.0 \\
\hline 2006 & 69 Heavy Rain & 331.1 & 43.5 & 290.5 & 23.5 \\
\hline 2007 & 89 Heavy Rain & - & - & 333.0 & 23.5 \\
\hline 2007 & Sepat & - & - & 186.1 & 39.5 \\
\hline 2007 & Krosa & 217.0 & 53.5 & - & - \\
\hline 2008 & Kalmaegi & 267.7 & 64.5 & 210.3 & 58.0 \\
\hline 2009 & Morakot & 287.0 & 30.0 & - & - \\
\hline
\end{tabular}

Note 1: "_" indicates no debris flow took place after the rainfall. Note 2: Rainfall calculation was based on Shieh et al. (2009). Note 3: Rain delay was based on the accumulated rainfall from 7 days before the effective rainfall. Note 4: Effective accumulated rainfall refers to the accumulated rainfall of a continuous rainfall from the beginning to the time of maximum rainfall intensity plus previous seven-day rainfall. Note 5: Limitation of rain guage only measured rainfall per 30min with temporal resolution. Note 6: All of rainfall events are real cases that triggered debris flows as reported in SWCB (2010).

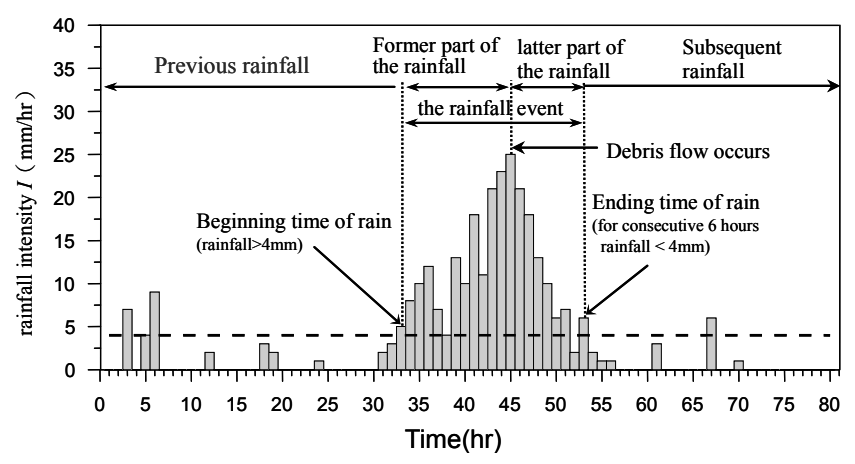

Fig. 8. Definition of rainfall events (after Jan et al., 2003).

flow occurrence has significant correlation with effective accumulated rainfall. Real case studies can be found in Jan et al. (2003). Effective accumulated rainfall refers to the "total rainfall calculated from the beginning of the event to the time of maximum intensity (see Fig. 8) plus previous seven days antecedent rainfalls" (Claine, 1980; Davies, 1997; Jan and Lee, 2004; Jakob et al., 2012). Of the 27 events, debris flows were recorded for 11 and did not occur during 16 listed in Tables 1 and 2. Rainfall events for both Aiyuzih river and the Tsushui river are plotted in Fig. 9. In the figure, rainfall intensity represents the maximum hourly rainfall. Events for which debris flows did occur are shaded black. The two diagonal lines represent minimum hydrologic conditions for debris flow occurrence. No debris flows occur at rainfall intensities less than $20 \mathrm{~mm} \mathrm{~h}^{-1}$ and using the intersection of these two lines, approximately $200 \mathrm{~mm}$ of effective accumulated rainfall appears to be threshold value for debris flow occurrence in these two river catchments. However, the threshold value for rainfall intensity is different for each catchment.

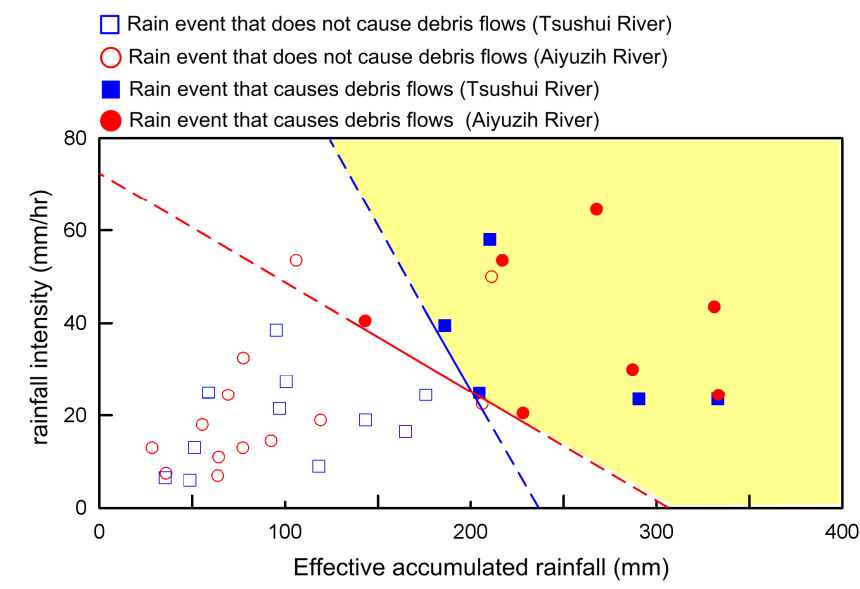

Fig. 9. Correlation between effective accumulated rainfalls and rainfall Intensity.

As shown in Fig. 9, for the same effective accumulated rainfalls, the rainfall intensity required to trigger debris flow in Aiyuzih river catchment area is smaller than the one of Tsushui river. This means that when the effective accumulated rainfall is less than $200 \mathrm{~mm}$, the probability of debris flow occurrence for Aiyuzih river catchment area is higher than Tsushui river.

On the contrary, when the effective accumulated rainfall exceeds $200 \mathrm{~mm}$, Tsushui river catchment area would get higher probability of debris flow occurrence than the other. This suggests when the effective accumulated rainfall is greater than $200 \mathrm{~mm}$, debris flows are more likely to happen in the Tsushui river catchment area. Similar regular patterns of hydrological conditions in combination with accumulated rainfall and rainfall intensity to trigger debris flows 
Table 2. Rainfall parameters from heavy rains without debris flow.

\begin{tabular}{|c|c|c|c|c|c|}
\hline \multirow[t]{2}{*}{ Year } & \multirow[t]{2}{*}{ Event } & \multicolumn{2}{|c|}{$\begin{array}{l}\text { Aiyuzih river } \\
\text { catchment area }\end{array}$} & \multicolumn{2}{|c|}{$\begin{array}{l}\text { Tsushui river } \\
\text { catchment area }\end{array}$} \\
\hline & & $\begin{array}{r}\text { effective accumulated } \\
\text { rainfall }(\mathrm{mm})\end{array}$ & $\begin{array}{r}\text { rainfall intensity } \\
\left(\mathrm{mm} \mathrm{h}^{-1}\right)\end{array}$ & $\begin{array}{r}\text { effective accumulated } \\
\text { rainfall }(\mathrm{mm})\end{array}$ & $\begin{array}{l}\text { rainfall intensity } \\
\qquad\left(\mathrm{mm} \mathrm{h}^{-1}\right)\end{array}$ \\
\hline 2002 & Rammasun & 119.1 & 19.0 & - & - \\
\hline 2002 & Nakri & 77.3 & 13.0 & - & - \\
\hline 2003 & Dujuan & - & - & 164.9 & 16.5 \\
\hline 2004 & Aere & - & - & 95.3 & 38.5 \\
\hline 2004 & Haima & 63.7 & 7.0 & - & - \\
\hline 2004 & Nanmadol & 55.6 & 18.0 & 97.13 & 21.5 \\
\hline 2005 & Matsa & 106.0 & 53.5 & 175.8 & 24.5 \\
\hline 2005 & Longwang & 69.4 & 24.5 & 100.6 & 27.5 \\
\hline 2006 & Chanchu & 92.5 & 14.5 & 51.2 & 13.0 \\
\hline 2006 & Kaemi & 64.3 & 11.0 & 143.3 & 19.0 \\
\hline 2006 & Saomai & 28.4 & 13.0 & - & - \\
\hline 2006 & Bopha & 35.9 & 7.5 & 58.8 & 25.0 \\
\hline 2007 & Ewiniar & 77.6 & 32.5 & 48.8 & 6.0 \\
\hline 2007 & Wipha & 206.2 & 22.5 & 118.1 & 9.0 \\
\hline 2007 & Pabuk & - & - & 35.4 & 6.5 \\
\hline 2008 & Fung-wong & 211.2 & 50.0 & - & - \\
\hline
\end{tabular}

Table 3. DEMs Used by this study.

\begin{tabular}{lll}
\hline $\begin{array}{l}\text { Data } \\
\text { period }\end{array}$ & Method & Source \\
\hline 2002 & aerial orthophoto (DEM) & Ministry of Interior \\
2005 & aerial orthophoto (DEM) & Soil and Water Conservation Bureau \\
2009 & airborne LiDAR (DEM) & Soil and Water Conservation Bureau \\
\hline
\end{tabular}

Note: Each grid size of used DEMs is $5 \mathrm{~m}$ and its accuracy of these DEMs ranges between $30 \mathrm{~cm}$ to $50 \mathrm{~cm}$.

agree well with real cases reported by Jan et al. (2003, 2004), Shieh et al. (2009) and Arattano et al. (2010).

\subsection{Analysis of sediment source}

High-precision DTMs derived from aerial orthoimages and airborne LiDAR DTM data sets were used to calculate hypsometric integrals of the Tsushui river and Aiyuzih river catchments for the years 2002, 2005, and 2009 listed in Table 3. Subtraction of the 2005 and 2009 DTM data set from the 2002 data set allowed comparison of elevation data for those different periods and identification of slope and river changes in the catchment areas.

\subsubsection{Hypsometric integral}

The hypsometric integral is the area beneath the curve which relates the percentage of total relief to cumulative percent of area and is often used to indicate topographic development of a catchment. The hypsometric integrals from 2002, 2005, and 2009 for the Tsushui river and Aiyuzih river catchment are compiled in Table 4. The hypsometric integrals for

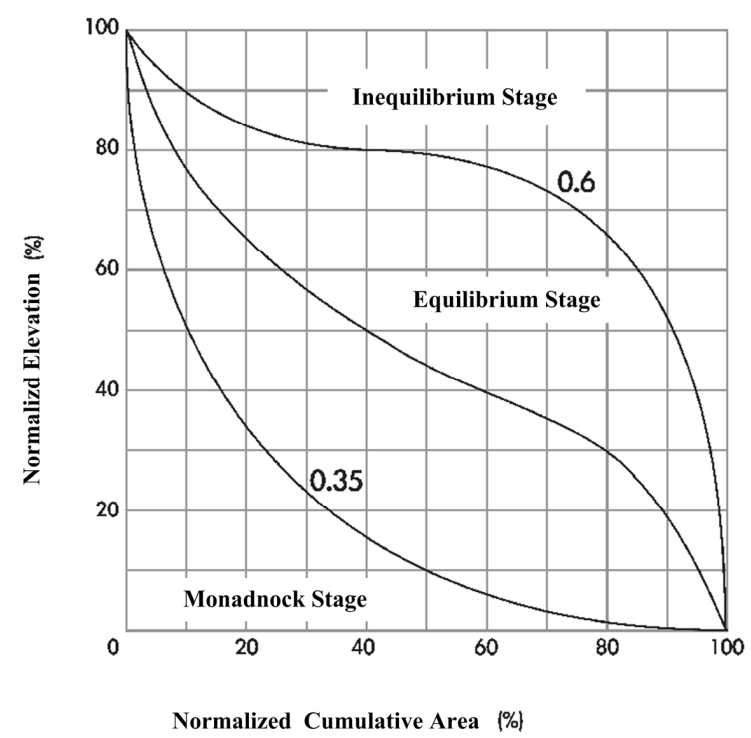

Fig. 10. Hypsometric integral analysis and terrain evolution classification (after Strahler, 1952).

both sub-catchment areas are greater than 0.6 , which according to hypsometric integral analysis (Strahler, 1952; Benda et al., 2003, 2005), and terrain evolution classification (see Fig. 10), suggest a state of non-equilibrium and a developing terrain. Therefore, sediment production processes such as erosion and debris flows are expected. 
Table 4. Annual hypsometric integrals in the two sub-catchment areas (after SWCB, 2010).

\begin{tabular}{lrr}
\hline Catchment & $\begin{array}{r}\text { Tsushui } \\
\text { Year }\end{array}$ & $\begin{array}{r}\text { Aiyuzih } \\
\text { river }\end{array}$ \\
\hline 2002 & 0.709 & 0.698 \\
2005 & 0.709 & 0.699 \\
2009 & 0.716 & 0.712 \\
\hline
\end{tabular}

\section{Grid Subtraction}

\begin{tabular}{|c|c|c|}
\hline 6 & 11 & 14 \\
\hline 11 & 13 & \\
\hline 16 & 14 & 16 \\
\hline
\end{tabular}

2nd DEM Grid Map (Post-event)

Variation of Volume

$=$ Result $x$ Unit grid area

\begin{tabular}{|c|c|c|}
\hline 3 & 10 & 15 \\
\hline 15 & 17 & \\
\hline 16 & 19 & 19 \\
\hline
\end{tabular}

1st DEM Grid Map

(Pre-event)

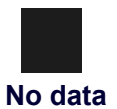

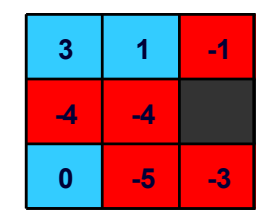

Results

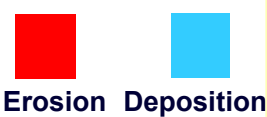

Fig. 11. Grid subtraction in post-event and pre-event digital terrain elevations (after Hsiao et al., 2011).

\subsubsection{Differences in 2002, 2005 and 2009 digital terrain model}

Direct grid subtraction of DTM data from years 2005 and 2009 from 2002 DTM data were used by ArcGIS 9.31 Spatial Analyst to quickly identify topographic changes in the Shenmu area. As shown in Fig. 11, a negative grid value of the subtracted DTMs means that the elevation of the terrain lowered and material was lost. Conversely, a positive value means material accumulation. The estimate of the total amount of sediment, eroded or deposited in the catchment area, is obtained by multiplying the obtained values for the grid unit area of the DTM (Hsiao et al., 2011; Lin et al., 2012).

Material loss and material accumulation relative to topographic location are illustrated in Fig. 12. It shows that the historical trend of overall terrain change is erosion. After typhoon Morakot in 2009, the total erosion in Tsushui and Aiyuzih river catchment area was respectively 6.56 and $19.14 \times 10^{6} \mathrm{~m}^{3}$ of sediment loss. Comparing the 2002-2005 and the 2005-2009 periods, it can be found that the sediment loss during 2005-2009 was over 4.4 to 167 times the sediment generated by the antecedent period. This change was more significant in the Aiyuzih river. In addition, as revealed by historical data shown in Table 1, rainfall events become more severe and prone to trigger the debris flow occurrence after 2005. For both of the river catchment areas, slopes were the main sources for sediment supply.

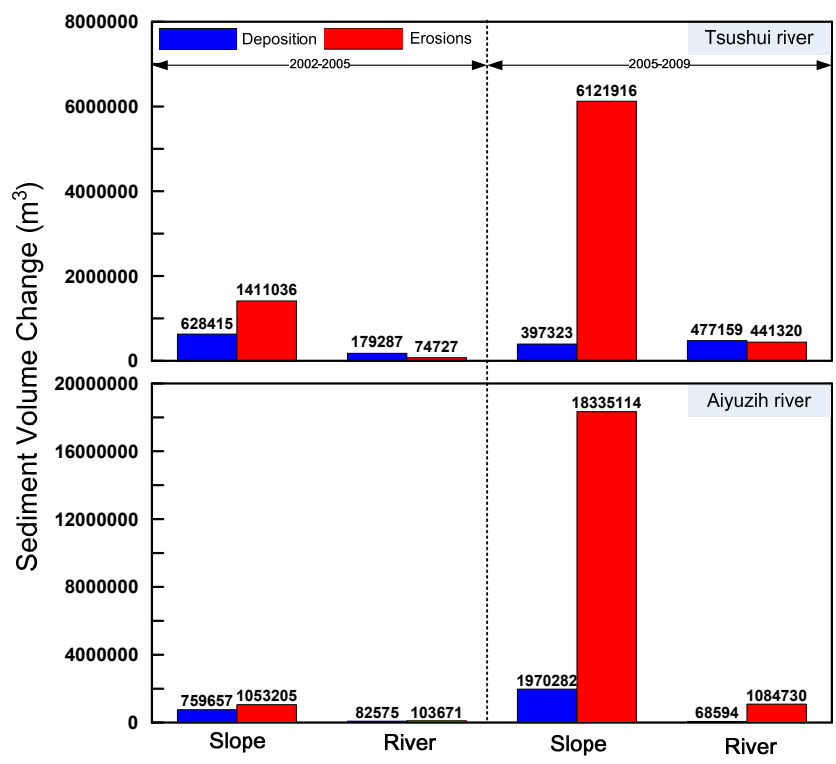

Fig. 12. Sediment volume changes in Tsushui river and Aiyuzih river catchment areas.

Results of DTM subtraction for the Shenmu area are plotted with aerial overlays from the same periods, as shown in Figs. 13 and 14. Red areas are areas of material erosion and blue area are areas of material deposition. According to these two figures, as far as Tsushui river catchment is concerned, during the 2009 typhoon Morakot, the primary collapse happened in the upstream East flank of the catchment. Scattered deposits are seen along the river with main deposits at the foot of slope failure on the downstream right flank and in the riverbed downstream of the Shenmu area. As far as Aiyuzih river catchment area is concerned, after typhoon Morakot, several large landslides occurred, the biggest one in the southwestern part (see Fig. 13). Several sediment deposits are still clearly visible at the source area. Moreover, field surveys confirm the above observations. It was documented that the two rivers have large volumes of sediment deposited on the river flanks and slopes, close to the catchment head (see Fig. 15).

\subsection{Erosions, deposits, and valley shape analysis}

Assessments of the erosion and deposition processes along the valley have been carried out by means of river cross section data from different periods to explore the erosion/deposits trends and valley changes associated with debris flows. The reason for this kind of analysis lays in the fact that, on average, V-shaped valleys are typical of the debris flow initiation segment, whereas U-shaped valleys represent debris flow movement (Chen and Su, 2001). According to the different available data sources, the assessments have been based on the historical DEMs and topographical surveys (see Table 5 and Fig. 16). Data accuracy and precision were very 

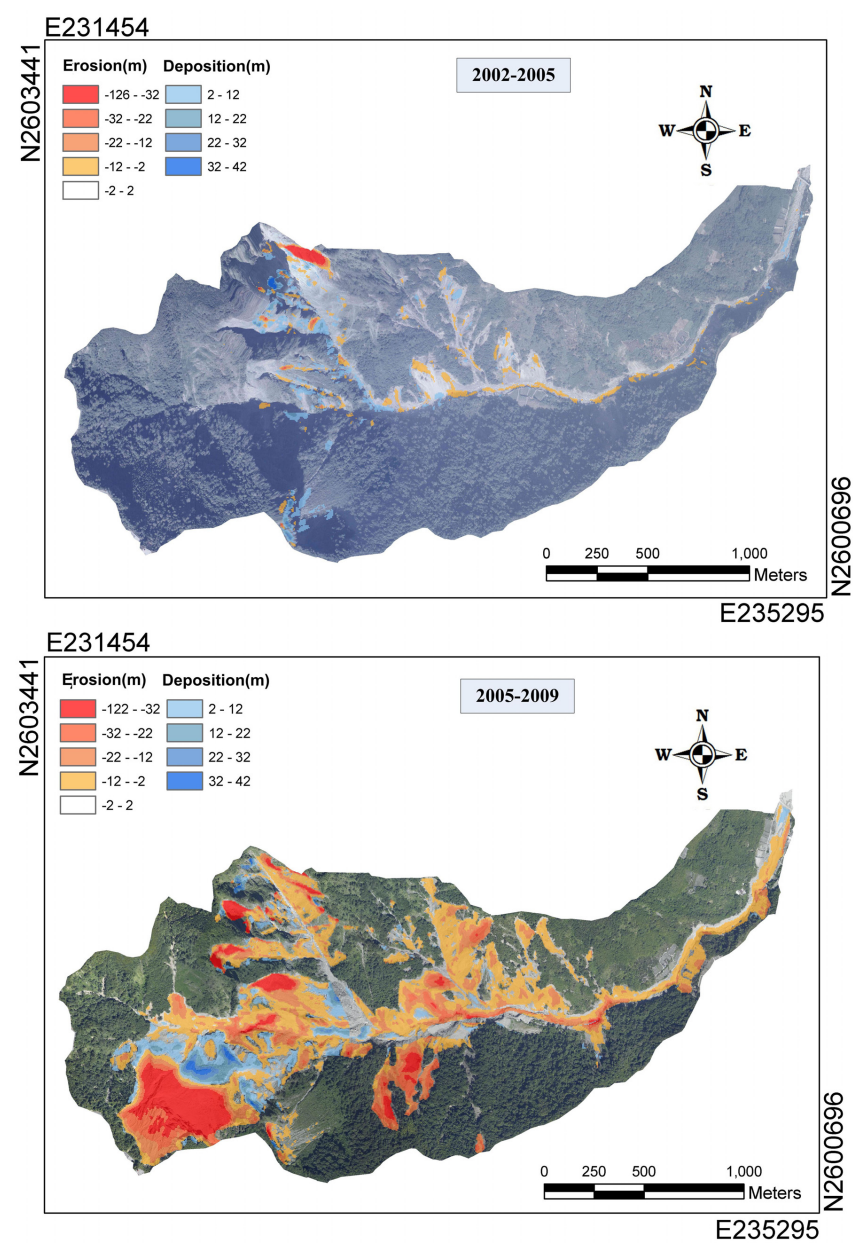

Fig. 13. Elevation changes (2002-2005 and 2005-2009 periods) after 2009 typhoon Morakot in Aiyuzih river catchment area.

rough, according to the different kinds of field measurement, and therefore only erosion and deposition trends and valley changes will be discussed and compared here.

\subsubsection{Erosions/deposits}

The analysis of erosion/deposition trends in both upstream and downstream sections of the Tsushui river and Aiyuzih river catchment areas are shown in Figs. 17 and 18. According to the figures, the two rivers constantly widened, especially after typhoon Morakot. Further, erosions happened to both upstream reaches while deposits occurred in downstream reaches.

\subsubsection{Valley shape analysis}

Valley shape changes in Shenmu area have been evaluated by means of in situ surveys. Chen and Su (2001) carried out some studies, based on field data, and tried to compare cross sections in different valley shapes. They found that if the river cross section changed from a $\mathrm{V}$ shape to a $\mathrm{U}$ shape
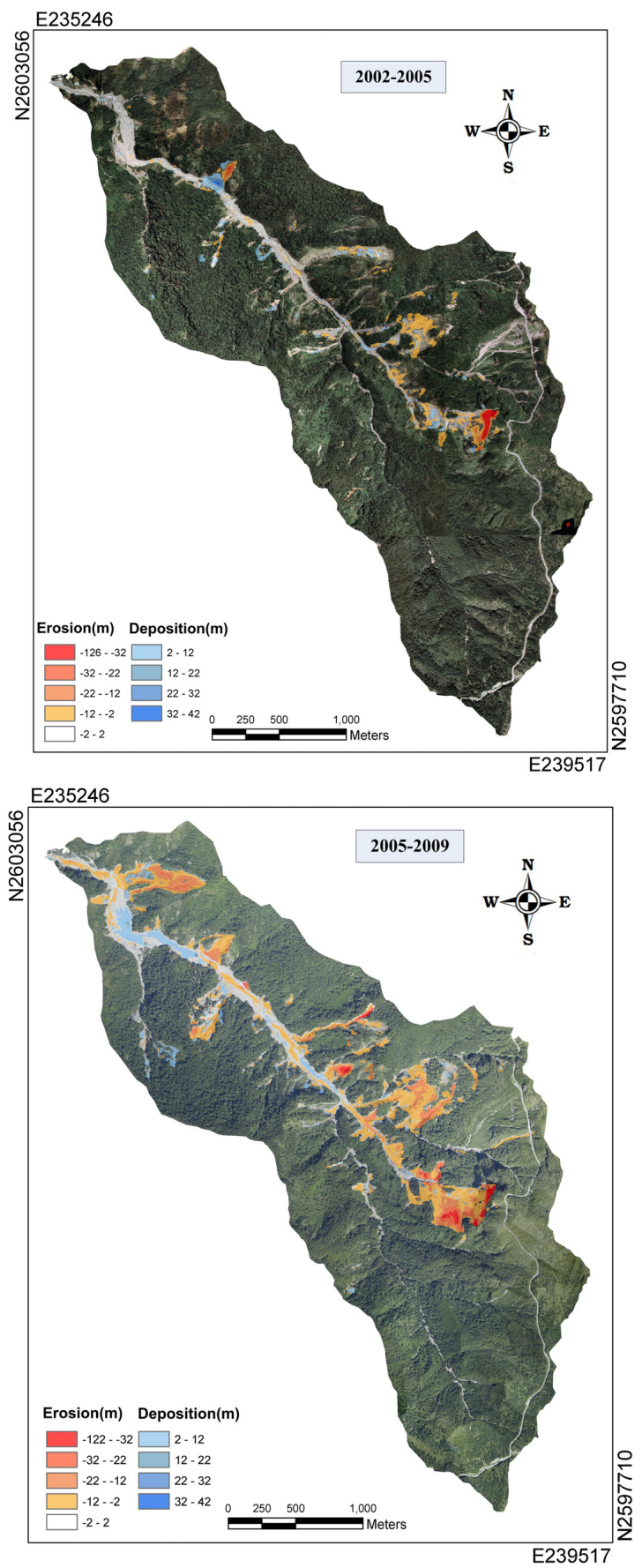

Fig. 14. Elevation changes (2002-2005 and 2005-2009 periods) after 2009 typhoon Morakot in Tsushui river catchment area.

after a debris flow, the V-U change would indicate a site for a debris flow occurrence. Figure 18 represents some cross sections of the Tsushui river, located approximately $900 \mathrm{~m}$ to $2500 \mathrm{~m}$ upstream of the downstream junction. In these figures, changes in the $\mathrm{V}$ and U-shapes, in the period from 2002 to 2009 (after typhoon Morakot), are indicated. The analysis of the DTMs can allow more precise quantification of 

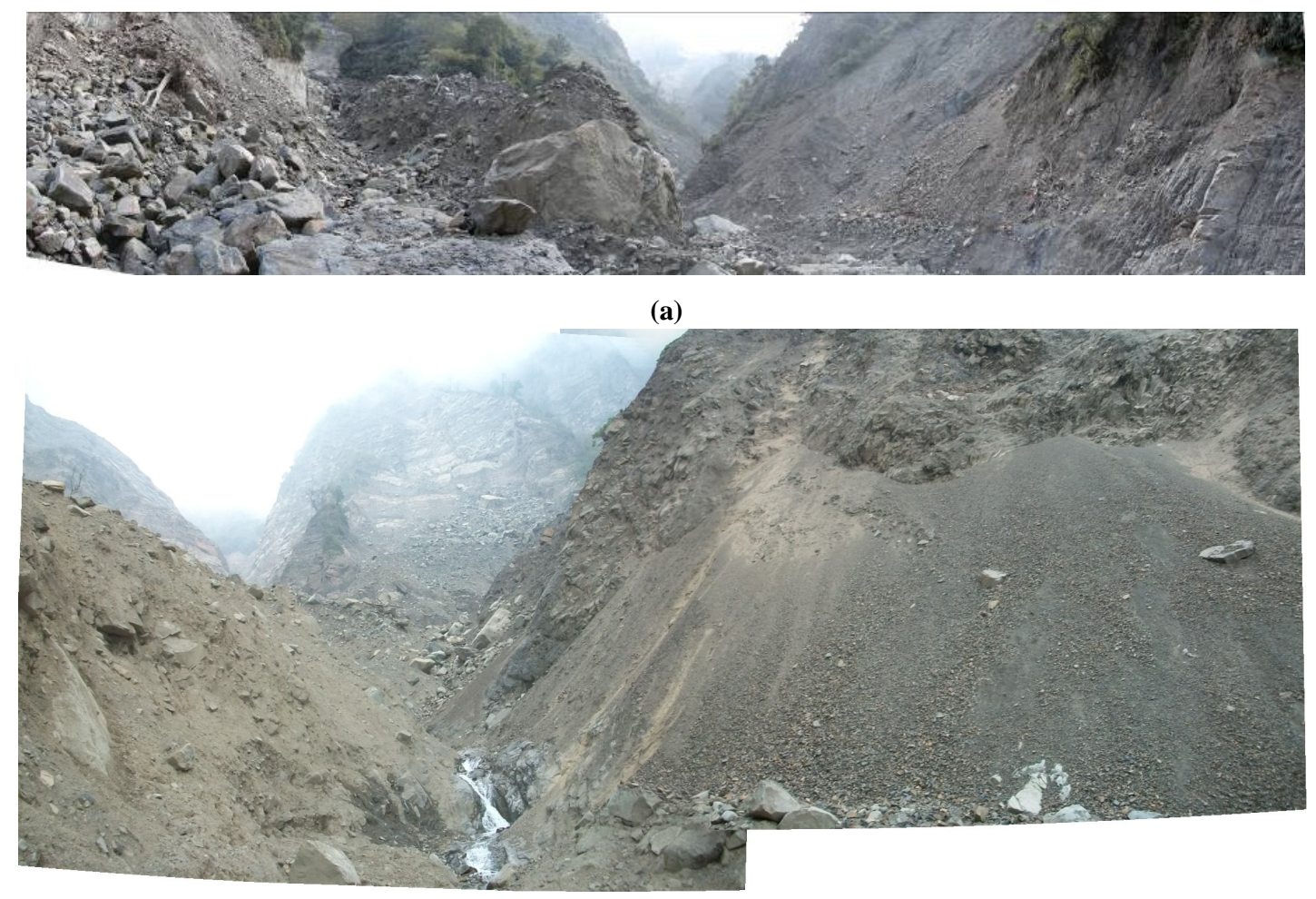

(b)

Fig. 15. Images of field observation along Tsushui river and Aiyuzih river in Shenmu area after typhoon Morakot (Date: 2009/12/04). (a) At location of $3193 \mathrm{~m}$ from the junction of Tsushiu river, the valley is V shaped and well developed rock joint are clearly visible along the river flanks. Due to the approximately $10 \mathrm{~m}$ thick deposit of sediment material on the river flanks and slope, about $100 \mathrm{~m}$ downstream, the valley changes into a U shape. (b) At location of $2600 \mathrm{~m}$ from the junction of Aiyuzih river, the valley is V-shaped, slope turns exposed bedrock. A large volume of sediment material remains in the river and slope similar to the Tsushiu river.

valley shape changes. Figure 19 contains some useful indications concerning landslides caused by typhoons in the past in Tsushui river. According to the figure, after typhoon Toraji in 2001, a significant collapse happened on the right-side flank, approximately $2500 \mathrm{~m}$ from the downstream junction. The total volumes involved in the collapse increased every year. Also after typhoon Mindulle in 2004, many landslides occurred in the upstream area. The debris was transported downstream by the surging water. The alternation in time of these landslides processes illustrates the transformation from V-shaped valleys to U-shaped valleys. Therefore, the upstream area of the Tsushui river is believed to be the sediment supply segment, that is the so-called "initiation segment", i.e. the area where the erosions and landslides initiate, supplying sediment to debris flows. This natural process probably started in 2002, as it is evident in the comparison of 2002 and 2005 DTMs. The process is presently moving upstream.

Regarding the Aiyuzih river catchment area, valley analyses suggest the entire catchment area is U-shaped, as shown in Fig. 17. The V-U valley change cannot be deduced from the comparison of the cross sections. Consequently, it is believed that the debris flow initiation segment is upstream the measured river section SEC20 shown in the figure (2300 $\mathrm{m}$ from downstream junction).

\section{Discussion on debris flow triggering factors}

As mentioned, the occurrence and magnitude of debris flows are influenced by three factors: rainfall characteristics, geologic conditions and topography. Below, these characteristics are summarized for each catchment.

\subsection{General assessment}

a. From a geological point of view, most of the rocks in the upstream Shenmu catchment areas are sandstone and thin shale, with clear layers. Furthermore, a fault and anticline pass through the catchment area, both of which moved during the 1999 Chi-Chi Earthquake, and further fragmented the geologic structure of the area.

b. In terms of topography, the shapes of the two catchment areas can be described as semi-circular, surrounded by mountains on three sides with an opening on one side. 
Table 5. River section elevation data.

\begin{tabular}{|c|c|c|}
\hline Data period & Source & Precision \\
\hline 2002 & aerial orthophoto (DEM) & \multirow{4}{*}{ \pm 30 to $50 \mathrm{~cm}$} \\
\hline 2005 & aerial orthophoto (DEM) & \\
\hline June 2009 & airborne LiDAR(DEM) & \\
\hline September 2009 & airborne LiDAR(DEM) & \\
\hline November 2009 & on-site river cross section survey & \multirow{2}{*}{ $\pm 2 \mathrm{~mm}+2 \mathrm{ppm}$ (Using Leica TS06 total station) } \\
\hline February 2010 & on-site river cross section survey & \\
\hline
\end{tabular}

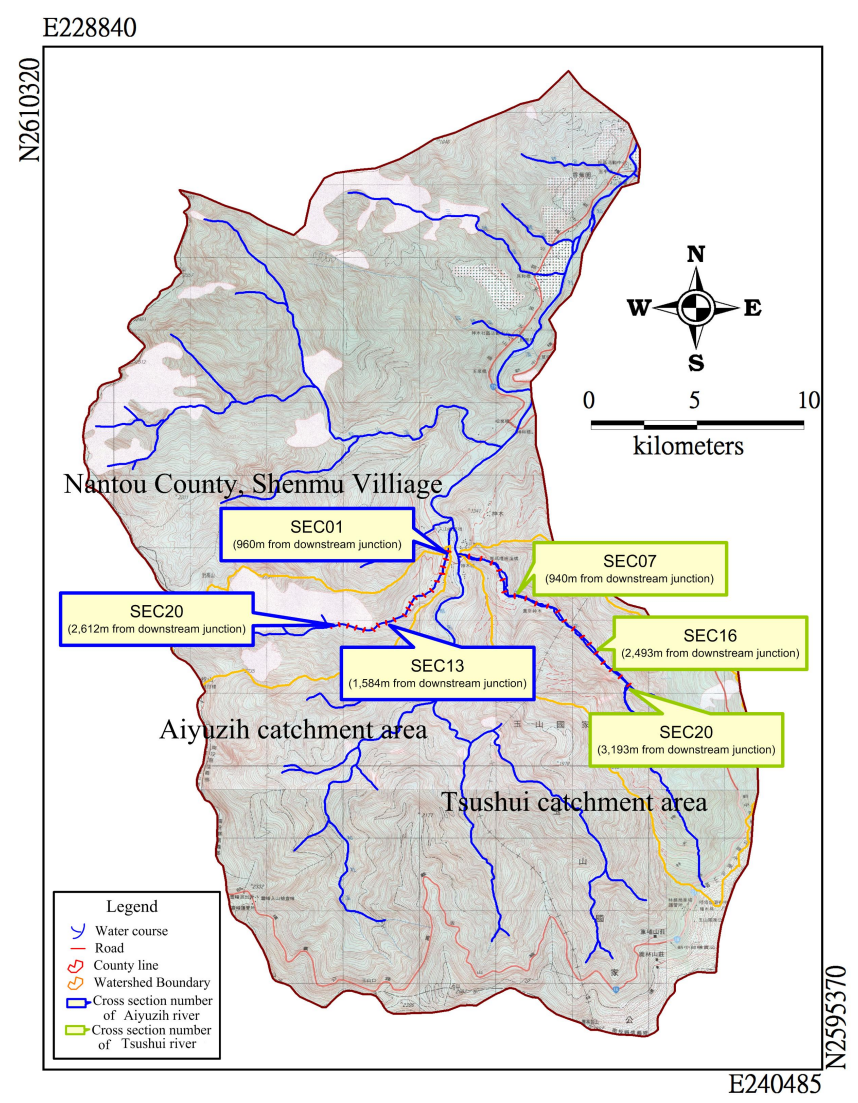

Fig. 16. Location of river cross sections.

This shape can easily develop gully erosions, landslides, and debris flows. Furthermore, the maximum elevation difference is more than $1500 \mathrm{~m}$. Moreover, the catchment areas are still young and river erosion is intense. Larger amounts of sediment are washed downstream, and slopes are eroded at the toe, with a sedimentation in riverbeds. According to site surveys, the slope gradients of the two sub-catchment areas are $15^{\circ}$ to $20^{\circ}$ at Tsushui river and $20^{\circ}$ to $26^{\circ}$ at Aiyuzih river. Riverbed gradients of this magnitude can sustain fluid-like debris flows (Harris, 1977; Takahashi, 1978)

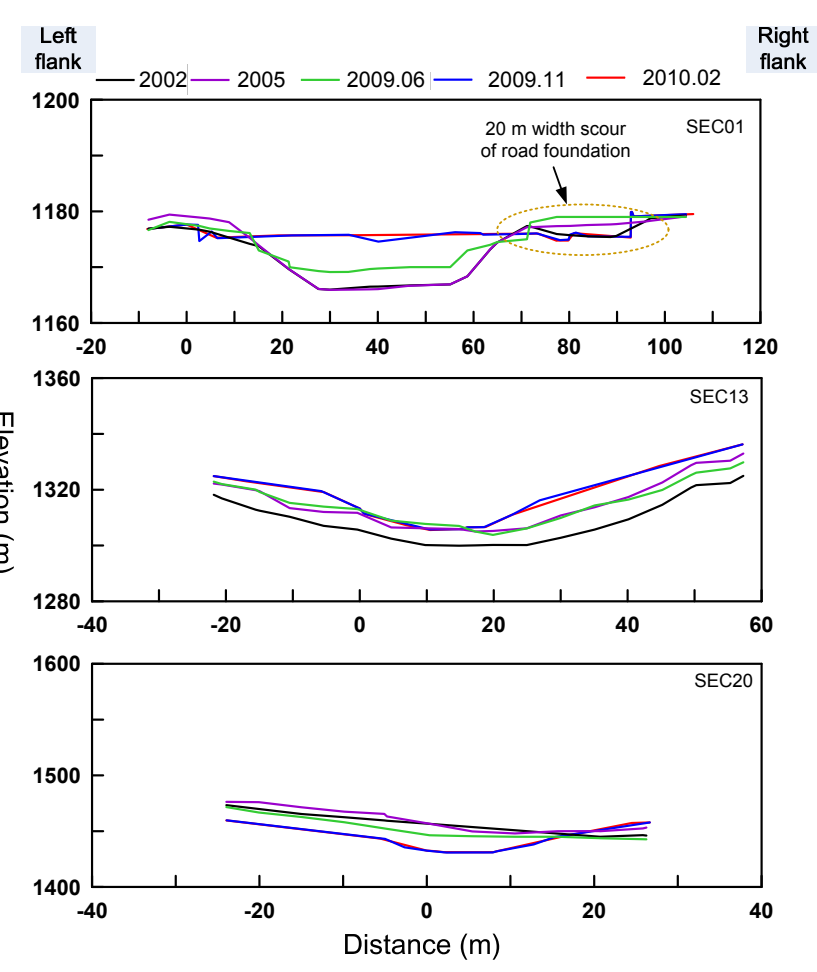

Fig. 17. River cross sections: SEC01, SEC13, SEC20 of Aiyuzih river catchment area.

c. Alishan has the heaviest rainfalls of all other sites in Taiwan. Affected by recent climate change, extreme and extended and heavy rainfalls are common. The annual average rainfall can reach $5000 \mathrm{~mm}$. Large amounts of water replenish the groundwater and increase soil water content through joint cracks. This also causes shale to absorb water and to breakdown after expanding. When soil has been saturated with water for a long time, it becomes easily affected by gravity and transports the deposits out of catchment area in the form of debris flows. 
Table 6. Debris flow occurring conditions.

\begin{tabular}{|c|c|c|c|}
\hline \multicolumn{2}{|c|}{ Catchment area } & Tsushui river & Aiyuzih river \\
\hline \multicolumn{2}{|c|}{ Material supply } & right flank collapse & collapse at source \\
\hline \multirow{2}{*}{ Hydrological conditions } & effective accumulated rainfall & \multicolumn{2}{|c|}{$200 \mathrm{~mm}$} \\
\hline & rainfall intensity & \multicolumn{2}{|c|}{$20 \mathrm{~mm} \mathrm{~h}^{-1}$} \\
\hline \multicolumn{2}{|c|}{ Initiation segment slope gradient } & $15^{\circ}$ to $20^{\circ}$ & $20^{\circ}$ to $26^{\circ}$ \\
\hline \multicolumn{2}{|c|}{ Distance between initiation segment and downstream junction } & $2500 \mathrm{~m}$ or more & $2300 \mathrm{~m}$ or more \\
\hline
\end{tabular}

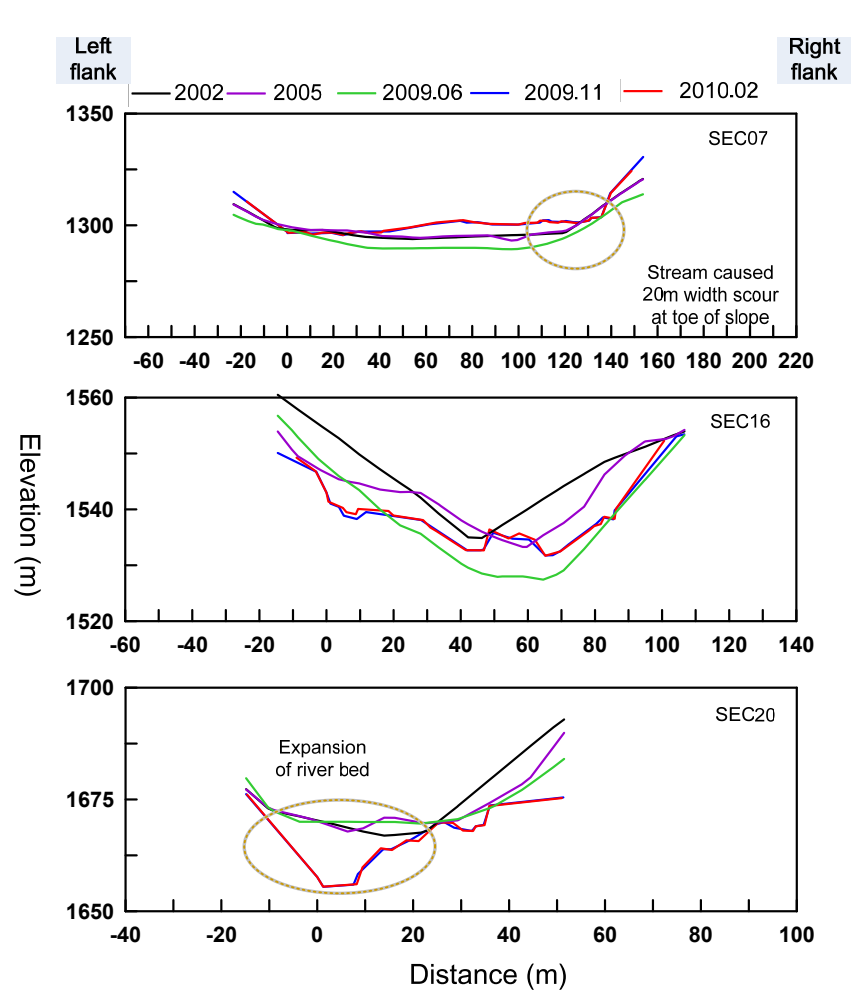

Fig. 18. River cross sections: SEC07, SEC16, SEC20 of Tsushui river catchment area

\subsection{Brief overview of debris flow occurring conditions}

\subsubsection{Tsushui river catchment area}

In Tsushui river catchment area, the sediment collapse along the slopes of the two flanks is the main source of debris flow, especially on the right flank. According to the analysis which has been carried out in Tsushui river catchment area, when the effective accumulated rainfall in a single rainfall exceeds $200 \mathrm{~mm}$, the sediment, located approximately at $2500 \mathrm{~m}$ (slope gradient between $15^{\circ}$ to $20^{\circ}$ ) or more from downstream junction on the right flank, may become unstable. After 2009 typhoon Morakot, about $0.47 \times 10^{6} \mathrm{~m}^{3}$ sediment volumes were deposited in upstream river bed reaches and near the junction of the river. Deposits near the junction

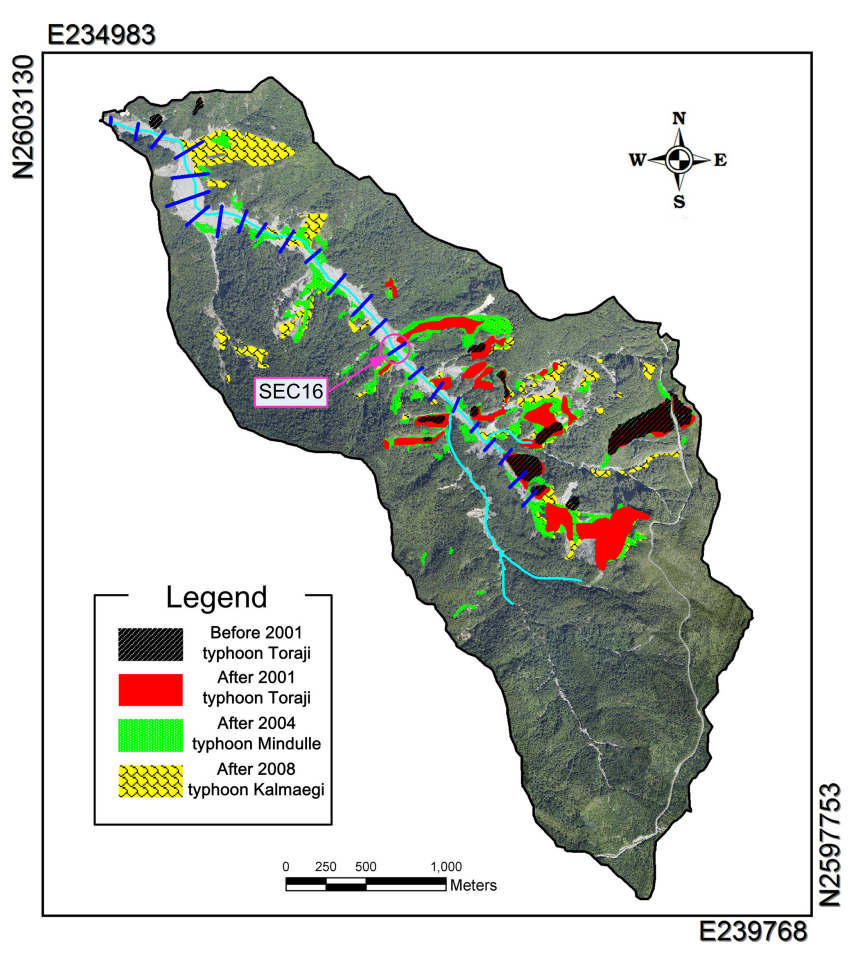

Fig. 19. Historical landslide distributions in Tsushui river catchment area.

were more than $20 \mathrm{~m}$ thick. In addition, $0.39 \times 10^{6} \mathrm{~m}^{3}$ sediment volumes were still lying on the slopes, especially on left-side tributary (see Figs. 12 and 14). In such a situation, the triggering mechanics can be easily predicted. As a consequence of rainfall intensities higher than $20 \mathrm{~mm} \mathrm{~h}^{-1}$, the water pressure increases suddenly within the soil pores. This decreases the effective stress, filling the pores of unstable soil with water, and then makes huge amounts of soil drop into river to generate flowing movement. Eventually, it causes debris flow under the effect of slope gradient and water discharge. Following mechanics like this, the sediment volumes deposited in the riverbed and on slopes can be mobilized to debris flow. 


\subsubsection{Aiyuzih river catchment area}

In the Aiyuzih river catchment area, the main material supply comes from the large collapse within the river source. If the effective accumulated rainfall in a single rainfall approaches $200 \mathrm{~mm}$ and rainfall intenstity exceeds $20 \mathrm{~mm} \mathrm{~h}^{-1}$, the collapsed sediment at $2300 \mathrm{~m}$ (slope gradient between $20^{\circ}$ to $26^{\circ}$ ) or more from the downstream junction may transform into debris flows, moving downstream. These conditions are similar to Tsushui river. However, After 2009 typhoon Morakot, approximately $1.9 \times 10^{6} \mathrm{~m}^{3}$ of sediment is still concentrated and deposited in the upstream part of the catchment (see Figs. 12 and 13). The location of this mass of sediment creates a direct supply of material to the river and is prone to cause the next event of debris flow. The probability of debris flow occurrence for future rainfall event can heuristically be considered higher than Tsushui river.

From the above-named analysis and observations, debris flow occurrence conditions are compiled in Table 6. According to the table, when effective accumulated rainfall exceeds $200 \mathrm{~mm}$, and rainfall intensity reaches $20 \mathrm{~mm} \mathrm{~h}^{-1}$, the right flank of Tsushui river, more than $2500 \mathrm{~m}$ from the downstream junction, may develop large-scale collapses. The same applies to the slope more than $2300 \mathrm{~m}$ from downstream junction at Aiyuzih river. This supplies abundant material and increases the likelihood of debris flows (SWCB, 2010).

\section{Conclusions}

During the flood season, large-scale debris flow disasters frequently occurred in Shenmu area. From a risk assessment point of view, this threatens the security of downstream receptors, Highway 21, with the risk of interrupting the connections to many villages. It is one of the most disaster-prone areas in Taiwan. This study proposes a simple and feasible process to quantify basic hydrological and topological conditions (i.e. rainfall characteristics, geologic conditions and topography), using multi-stage DTMs and aerial images (before and after events), historical rainfall data and field survey. Through rainfall event analysis of real cases, the proposed approach helps to identify corresponding temporal and spatial patterns or trends of debris flow occurrence. Furthermore, a series of field surveys and in-site imaging of debris flow disasters confirmed the evidence of debris flow occurrence. The analysis suggests that both the Tsushui river and Aiyuzih river catchment areas have continuous geological activity. Riverbed movement is intense, and huge amounts of sediment, estimated by comparison of DTMs, have been recently deposited in the rivers and at mid-slopes. The main sediment supply comes from $2300 \mathrm{~m}$ (or more) from the downstream junction. Rainfall analysis suggests when the effective accumulated rainfall in a single rainfall reaches $200 \mathrm{~mm}$, and when the rainfall intensity reaches $20 \mathrm{~mm} \mathrm{~h}^{-1}$, the likelihood for debris flow is high. Probably due to recent extreme climate changes, the average rainfall in the Shenmu area for the past five years has increased to approximately $5000 \mathrm{~mm}$. This can facilitate the processes of debris flow formation and triggering.

As a result, debris flows are more frequent in the Shenmu area. Therefore, we recommend maintaining, monitoring and conducting comprehensive geotechnical surveys in this area. Furthermore, hydrological and geological surveys from upstream, midstream, and downstream areas should be consolidated to compile relevant information for future debris flow analysis and provide a reference for disaster prevention and evacuation of the residents by the government. This will improve the early warning system, prevention, and risk management and strengthen monitoring and prevention mechanisms.

\section{Supplementary material related to this article is available online at: http://www.nat-hazards-earth-syst-sci.net/12/3407/2012/ nhess-12-3407-2012-supplement.zip.}

Acknowledgements. This work is a partial result of the studies funded by research contract SWCB-99-087, Soil and Water Conservation Bureau, ROC. The authors express their sincere gratitude for the support.

Edited by: L. Franzi

Reviewed by: three anonymous referees

\section{References}

Anderson, S. A. and Sitar, N.: Influence of stress path on soil strength parameter and analyses of rainfall-induced failure, Eng. Geol. Geotech. Eng., 27, 1-16, 1991.

Arattano, M. and Franzi, L.: Analysis of different water-sediment flow processes in a mountain torrent, Nat. Hazards Earth Syst. Sci., 4, 783-791, doi:10.5194/nhess-4-783-2004, 2004.

Arattano, M., Conte, R., Franzi, L., Giordan, D., Lazzari, A., and Luino, F.: Risk management on an alluvial fan: a case study of the 2008 debris-flow event at Villar Pellice (Piedmont, N-W Italy), Nat. Hazards Earth Syst. Sci., 10, 999-1008, doi:10.5194/nhess10-999-2010, 2010.

Ashida, K., Egashira, S., and Ohtsuki, H.: Dynamic behavior of a soil mass produced by slope failure, Annuals, Disaster Prevention Research Institute, Kyoto University, No26B-2, 315-327, 1983.

Benda, L., Veldhuisen, C., and Black, B.: Tributary confluences, debris flows, and channel morphology, Geol. Soc. Am. Bull., 115, 1110-1121, 2003.

Benda, L., Hassan, M. A., Church, M., and May, C. L.: Geomorphology of steepland headwaters: the transition form hillslopes to channels, J. Am. Water Res. Assoc., 41, 835-851, 2005.

Chen, H. and Su, D. Y.: Geological factors for hazardous debris flows in Hoser, central Taiwan, Environ. Geol., 40, 1114-1124, 2000.

Claine, N.: The rainfall intensity duration control of shallow landslide and debris flows, Geogr. Ann., 62, 23-27, 1980. 
Davies, T. R.: Using hydroscience and hydrotechnical engineering to reduce debris flow hazards, in: Debris-flow hazard mitigation: mechanics, prediction and assessment, edited by: Chen, C. L., ASCE, New York, 787-810, 1997.

Einstein, H. A.: River sedimentation, Handbook of Applied hydraulics, McGraw-Hill, New York, 79-105, 1964.

Franzi, L.: On the variability of sediment concentration in currents on steep slopes: a simplified approach, J. Phys. Chem. Earth, 27, 1551-1556, 2002.

Franzi, L.: Flood risk management in rivers and torrents, Risk Management for the Future - Theory and Cases, InTech, ISBN: 978953-51-0571-8, 2012.

Guzzetti, F., Peruccacci, S., Rossi, M., and Stark, C. P.: The rainfall intensity-duration control of shallow landslides and debris flows: an update, Landslides, 5, 3-17, 2008.

Harris, C.: Engineering properties, groundwater conditions, and the nature of soil movement on a Solifluction slope in North Norway, Q. J. Eng. Geol. Hydrogeol., 10, 27-43, 1977.

Hsiao, C. Y., Hsieh, P. S., and Chi, S. Y.: Assessing volume earthwork by using unconventional photogrametry, The Second World Landslide Forum, 2011.

Imaizumi, F., Sidle, R. C., and Kamei, R.: Effects of forest harvesting on the occurrence of landslides and debris flows in steep terrain of central Japan, Earth Surf. Proc. Landf., 33, 827-840, 2008.

Jakob, M. and Hungr, O.: Debris-flow Hazards and Related Phenomena, Springer, UK, 2005.

Jakob, M., Owen, T., and Simpson, T.: A regional real-time debris-flow warning system for the District of North Vancouver, Canada, Landslide, 9, 165-178, 2012.

Jan, C. D. and Lee, M. H. : A debris-flow rainfall-based warning model, J. Chinese Soil Water Cons., 35, 275-285, 2004 (in Chinese).

Jan, C. D., Lee, M. H., and Huang T. H.: Effect of rainfall on debris flow in Taiwan, Proceedings of the International Conference on Slope Engineering, Hong Kong, 2, 741-751, 2003.

Jan, C. D., Lee M. H., and Wang J. S.: A rainfall-based debris-flow warning model and its application in Taiwan, Proceedings of the 2004 International Conference on Slopeland Disaster Mitigation, Taipei, Taiwan, 111-119, 2004.

Johnson, A. M.: Physical processes in Geology, Freeman, Cooper and Co., 1970.
Lin, B. S., Ho, H. C., Chi, S. Y., Tsao, T. C., Yin, H. Y., Lo, W. C., and Hsu, S. M.: Discussions on debris flow induced factors of Shenmu watershed in Taiwan", European Geosciences Union, General Assembly 2011, 13, EGU2011-13594, Vienna, Austria, 3-8 April, 2011.

Lin, B. S., Hsiao, C. Y., Leung, W. Y., and Chi, S. Y.: Using airborne LiDAR technology to analyze landslide hazards in Shih-men watershed", European Geosciences Union, General Assembly 2012, Vol. 14, EGU2012-2884, Vienna, Austria, 22-27 April, 2012.

Nilsson, B.: Development of a depth-integrating water sampler, UNGI Rapport 2, Uppsala University, Department of Physical Geography, 1969.

Passmore, D. G., Harrison, S., Winchester, V., Rae, A., Severskiy I., and Pimankina, N. V.: Late Holocene debris flows and valley floor development in the northern Zailiiskiy Alatau, Tien Shan mountains, Kazakhstan, Arct. Antarctic Alp. Res., 40, 548-560, 2008.

Pierson, T. C.: Flow behaviour of channelized debris flows, Mount S. Helens, Washington, in Hillslope processes, edited by: Abraham, A. D., Boston, Allen \& Unwin, 269-296, 1986.

Pierson, T. C. and Costa, J. E.: A rheological classification of subaerial sediment water flows, Geological Society of America, Rev. Eng. Geol., 7, 1-12, 1987.

Shieh, C. L., Chen, Y.-S., Tsai, Y. J., and Wu, J. H.: Variability in rainfall threshold for debris flow after the Chi-Chi earthquake in central Taiwan, Int. J. Sediment Res., 24, 177-188, 2009.

Sidle, R. C., Pearce, A. J., and O'Loughlin, C. L.: Hillslope stability and land use, American Geophysical Union, Water Resourc. Monogr., 11, Washington, DC, 140 pp., 1985.

Soil and Water Conservation Bureau (SWCB): Field investigation of mechanism and potential analysis for sediment disaster in Shenmu Village, Shinyi Town, Nantou County, 591 pp., 2010 (in Chinese).

Strahler, A. N.: Dynamic basis of geomorphology, Geol Soc. Am. Bull., 63, 923-938, 1952.

Takahashi, T.: Mechanical characteristics of debris flow, J. Hydraul. Div., 8, 1153-1169, 1978.

VanDine, D.: Debris flows and debris torrents in the Southern Canadian Cordillera, Can. Geotech. J., 22, 44-68, 1985.

Vanoni, V. A.: Sedimentation engineering, ASCE Manual and Reports on Engineering Practice, 54, 191-260, 2006.

Water Resources Agency: available at: http://wrb.gov.tw (last access: 15 January 2012), 2012. 